\title{
Journal of Applied Linguistics
}

Vol 1, No 1 (2019), pp.45-57

Available at:

https://www.e-journal.unper.ac.id/index.php/ALTICS/issue/archive

\section{Promoting Students' Speaking Spontaneity through Games}

\author{
Diyah Rofa Abdulah \\ Universitas Perjuangan Tasikmalaya \\ Diyahrofa8@gmail.com
}

\begin{abstract}
This paper reports on speaking spontaneity. Having ability to speak spontaneously is a plus point and measuring the success of students to get high grades in the schools. Unfortunately, not everyone can speak spontaneously. Promoting students' speaking spontaneity through games in teaching academic English speaking to students who are learning english as a foreign language in a junior high school, West Java, Indonesia is very important. The objective of this research is to find out what games that teacher used to promote students' speaking spontaneity and to know the students' responses through the implemented games. This research was conducted qualitatively by employing the method of descriptive research. The study was conducted towards students in IX graders at a Junior High School of Tasikmalaya. The researcher collected the data by using observation and questionnaire. From the research findings, it can be concluded that the teacher used five games, such as Bingo Game, Stars Game, Dorr Game, Jumping Game, and Line Game to promote students' speaking spontaneity and the students' response towards the implemented game chose the Stars Game as the most interested game among the others because of the use of realia such as stars in learning process.
\end{abstract}

Keywords: teaching English, teaching speaking, promoting speaking, speaking spontaniety, games.

\section{INTRODUCTION}

Nowadays, speaking spontaneity has become an important thing in speaking skill, because having ability to speak spontaneously is a plus point and measuring the success of students to get high grades in the schools (Ramdani \& Rahmat, 2018, p. 388). Unfortunately, not everyone can speak spontaneously. Some of people need to prepare a long time to think before speaking, some of them have to write first about what they are going to speak. Almost everyone knows that there are two kinds of conventional techniques. Modern techniques and traditional techniques. Recently, modern techniques are growing and developed so faster to ease students in learning process. To promote speaking spontaneity, Harmer (2007, p. 345) proposed that technological tools and materials may help students in promoting their speaking spontaneity skills. It is useful to apply modern tool, for example: internet. Internet can be used whenever and everywhere, especially in the city area. For some schools in the city, internet is not a big problem because of it is always running well with high speed internet.

However, not all of schools have the access to technological tools such as internet for learning speaking. The use of internet to promote students' speaking spontaneity skills for some schools in the 
village can be a big problem, the internet is not always good there. Up to this point, it is quite obvious that the methods and techniques that used by the teacher will promote the students' speaking skills. This research provides the readers with empirical insight on how speaking spontaneity can be promoted through implementing a simple game. This study enlighten the researcher, English as Foreign Language teachers, and educational practitioners that speaking spontaneity is one of the aspects of speaking that cannot be ignored. Hence, the research towards the strategies to promote this aspect is considered important to be conducted as for promoting students to speak spontaneously to prepare them in this $21^{\text {st }}$ century learning which English is become very essential and thus being able to speak spontaneously can be a plus point.

\section{Teaching Speaking}

Teaching speaking is a great challenge for every teachers, especially in teaching English as foreign language. In a large class, teaching English speaking has become a great challenge for teachers (Ramdani \&Rahmat, 2018, p. 388). To solve this issue, Yegani and Jodaei (2017, p. 85) advised that language teachers should be able to use strategies to improve learners' meaningful communication in relevant topics using 'communication derives essentially from interaction' (Rivers, 1987).

According to Kroeker (2009, p. 16) to maximize the conversation class time for conversational practices is not easy in a speaking class. The goal of teaching is communication, then teaching communication or teaching speaking must be means of learning about language. Hussain (2017, p. 14) said that language was the priority in speech. Teachers and students of English as Foreign Language in the classroom are better to learn by using the target language about how to make a good conversation in speaking. Based on Rahmawati (2017, p. 1) native speakers of English are not the largest language population in the world but English has become lingua franca as the largest in global use. In other side, almost every students at school have great difficulties in speaking English (Rahmawati, 2017, p. 1). Students have the chance or opportunity to increase conversation in English speech. Next,students are pursuing their academics, it must be a very beneficial effort for students from various perspectives. Kosar and Bedir (2014, p. 1) (as cited in Rahmawati, 2017, p. 1) mentioned that English has become prominent in this life as second or as foreign language, and having ability to speak spontaneously is a plus point. 


\section{Journal of Applied Linguistics}

1(1), November 2019

\section{Speaking spontaneity}

Speaking spontaneity can be defined as an ability to speak spontaneously to be a good speaker. Speaking has become one of what the literature described as basic skill in mastering language (Bozkirli \& Er, 2018, p. 66). Speaking entails numerous 'mental processes' as the interaction which relates to how students experience them selves in the process of socialization integrated with 'the society around them' (Goh, 2014; Willis 2015). In addition, Yegani and Jodaei (2017, p. 85) contended that speaking was one of the four integral elements to connect with others, and thus the teacher should be able to construct the language activity in speaking, especially for English as Foreign Languagelearners by considering related to factors, conditions, and components.

It is no doubt that to speak spontaneously is a challenging task, especially for English as Foreign Language learners. Widodo (2015b) (as cited in Ramdani \& Rahmat, 2018, p. 388) pinpointed that speaking was a complex activity for students in an English as Foreign Language speaking classroom since students have to express both content knowledge and linguistic resources in an appropriate way. Humphries, Burns, and Tanaka (2015) (as cited in Ramdani and Rahmat, 2018, p. 388) also found that foreign language learners often faced difficulties to speak up due to various factors while having speaking spontaneity activity. In consequent, teachers possess an essential role to design a meaningful speaking task, which can engage students in learning speaking spontaneity activities (Widodo, 2015a) (as cited in Ramdani and Rahmat, 2018, p. 388).

There are some factors affecting speaking skill which pertinent to speaking spontaneity are reviewed by some researchers. One of the studies shows that to promote the development of students' speaking spontaneity skill has many factors (Boonkit, 2010, p. 1305). In addition, The results point out that choosing topic based on the students' agreement such as using games in learning speaking spontaneity urged the participants to feel enjoy, happy, comfortable, persuaded to speak English spontaneously, and improve the speaker confidence among English as Foreign Language learners. The results also revealed that the use of appropriate activities like games for English speaking skill can be a good strategy to decrease speakers' anxiety in promoting speaking spontaneity.

\section{Games in Teaching Speaking}

In the field of education, every teacher should be competent in conducting matching game to curriculum content and objective. Allsop and Jessel (2015, p. 1) 


\section{Journal of Applied Linguistics \\ 1(1), November 2019}

mentioned that teachers need to decide and choose which games can be appropriate for students to be able to speak spontaneously. Next, students can use the games to manifest specific learning in speaking English spontaneously. Astutie (2018, p. 45) in her research shows that using games make students active in speaking spontaneity and learning seriously in relax condition. Looking at the role of teacher, both using games for teaching, or teaching through game design should be aware of learning process to explore the students' potential in speaking spontaneity.

Felicia (2009, p. 1) (as cited in Allsop and Jessel, 2015, p. 1) said that different games genre have a good benefit for students in education, and decided to apply games is good choice to improve students' speaking skill especially in spontaneity. Students can learn, share, and develop the understanding of the concepts with other students. This will be very useful and help in speaking spontaneity by using games. However, Yien (2011, p. 1) emphasized that the aim of games was to explore the influence of applying a gamebased learning in speaking spontaneity. Rahmawati (2017, p. 1) cited in her research, using games have improved students' speaking ability significantly. The students have good response and positive attitude in speaking spontaneity.
In the field of education, students have to speak up is also one of the main another challenge for English as Foreign Language learners. Commonly, students feel shy, nervous, anxiety, think do not have enough self-confidence and knowledge, also lack of vocabulary and not good in grammar. Students think there are too many problems when the students have to learn the speaking tasks in the classroom spontaneously. For instance, Urrutia and Vega (2010, p. 11) carried out that in promoting speaking skills, selfconfidence, vocabulary knowledge, diffidence, class environment, and fear of being despised was influenced learners' oral performance spontaneity. However, Yalcin and Incecay (2014, p. 2620) noted that reluctant to speak sometimes can appear to be problematic for students in speaking spontaneously because of lack of motivation and increased anxiety in the target language. However, the previous researchers have not focused on research about promoting students' speaking spontaneity, especially by using game. Therefore, this research about promoting students' speaking spontaneity through game is very important.

As previously discussed, speaking in English has been investigated under research and been resulted solution which tend to utilizing technological tools to assist students in promoting speaking skills 
(e.g. Harmer, 2007, p. 345; Urrutia \& Vega, 2010, p. 11). To void this gap, anchored with Bandura's socio-cognitive theory 1986 (as cited in Harinie, 2017, p. 1), the researcher intended to conduct a descriptive research to seek whether speaking spontaneity can be promoted by utilizing games. The little attention has been paid to the utilization of games particularly concerning for promoting students' speaking spontaneity. According to Sevy-Biloon (2017, p. 84) in an English language classroom, there are so many various types of activities to educate that can choose to use. Hence, the researcher choose the game in the research to know the students' speaking spontaneity skill in the school which far from modern tools by using game to promote the students' speaking spontaneity. Here, the game was motivated by the teacher.

\section{METHOD}

The descriptive research was conducted in Junior High School students studying English as a Foreign Language concerning to their speaking spontaneity. The study was conducted towards students in IX graders at a Junior High School of Tasikmalaya. There are 20 participants, consists of 14 male participants and 6 female participants. They have similar age of 15 years old in different gender to vary the data. The research was conducted at SMP Negeri 15 Tasikmalaya. It is located in Jalan Tamanjaya Tamansari, Kota Tasikmalaya. It is one of Junior High Schools in Tasikmalaya, West Java, Indonesia.

The researcher collected the data by using observation and questionnaire. The observation focuses on students' speaking spontaneity during the teaching and learning process by using game. The researcher used the questionnaire of Likert scale. The statements was devided into five categories: strongly agree, agree, neutral, disagree, and strongly disagree.

The questionnaire focuses on students' response towards the game. The questionnaire used Bahasa Indonesia with some considerations: It provided students a fair opportunity to express them selves, regardless of their actual skills in English, it encouraged participants to speak freely about their feelings and experiences, it made the questionnaire more comfortable to express their thoughts and opinions. The researcher analyzed the data used qualitative data by applying methodological triangulation (Delefosse at al., 2016, p. 148). The qualitative data collected from the observation and questionnaire of Likert scale.

This research was conducted by employing the method of descriptive research and ethnografy as the research design. According to Creswell (2014, p. 14) ethnography is a research design that 
help the researcher to study action, scores of the students' speaking language, and behaviours. Layman (1972, spontaneity which modified by the p. 219) noted in scoring the result of researcher: students' speaking test. Table 1 shows the Table 1. Score and Criteria of Spontaneity.

\begin{tabular}{|c|c|c|c|}
\hline Classification & Score & Criteria & Description \\
\hline Excellent & $9.6-10$ & $\begin{array}{l}\text { Their speaking is excellent of } \\
\text { spontaneity. }\end{array}$ & They speak after 2 seconds. \\
\hline Very good & $8.6-9.5$ & $\begin{array}{l}\text { Their speaking spontaneity is very } \\
\text { good. }\end{array}$ & They speak after 4 seconds. \\
\hline Good & $7.6-8.5$ & $\begin{array}{l}\text { Their speaking is good of } \\
\text { spontaneity. }\end{array}$ & They speak after 6 seconds. \\
\hline Fairly good & $6.6-7.5$ & $\begin{array}{l}\text { Their speaking is good enough of } \\
\text { spontaneity. }\end{array}$ & They speak after 8 seconds. \\
\hline Fair & $5.6-6.5$ & $\begin{array}{l}\text { Their speaking is fair of } \\
\text { spontaneity. }\end{array}$ & They speak after 10 seconds. \\
\hline Poor & $3.6-5.5$ & $\begin{array}{l}\text { Their speaking is low of } \\
\text { spontaneity. }\end{array}$ & They speak after 12 seconds. \\
\hline Very poor & $0.0-3.5$ & $\begin{array}{l}\text { Their speaking is very low of } \\
\text { spontaneity. }\end{array}$ & They speak after 14 seconds. \\
\hline
\end{tabular}

(Layman 1972 modified by observer)

\section{FINDINGS AND DISCUSSION}

This research focuses on describing results of the research that taken from the observation and questionnaire. Based on the research findings, the teacher used some games such as Bingo Game, Stars Game, Dorr Game, Jumping Game, and Line Game in delivering the lesson to challenge the students to be spontaneous speakers. From the five implemented games, the students' response towards the implemented games chose stars game as the most interseting game to participate spontaneously in speaking practice.

\section{Bingo Game}

Bingo game was a simple game. The role of this game: the students need to raise a hand and following by saying bingo to answer the questions. For playing this game, first, the teacher delivering the material about congratulations! (expressions and respons of congratulations). Then, the teacher gave some questions to the students and the students competed with other students to answer the questions. To the students who could answer the questions correctly, the teacher would give a point.

\section{Stars Game}

Stars game was a fun game. The role of this game: the students need to answer the questions correctly for collecting the stars that teacher made from paper. For playing this game, first, the teacher delivering the material about let's start our wall magazine! (modal: will). Then, the teacher devided the students into four groups. Next, the teacher gave some questions to 
the students. To the groupwho could answer the questions correctly, the teacher would give a starsfor them. Every groups had the same chance to collect the stars as much as they can answer the questions correctly.

\section{Dorr Game}

Dorr game was an easy game that needs concentration to played. This game was played by counting and following by a word “dorr". The role of this game: every students need to countwith listen carefully and pay attention to the other students to continue the counts. For playing this game, first, the teacher delivering the material about let's start our wall magazine! (modal: must). Then, the teacher commanded the students to count for playing the game, for example: the student A said one, student B said two, student C said "dorr", student D said four, student E said five, student F said "dorr" and so on. Here, the teacher could change the count by mentioning names of fruits, animals, and others. To the students who could not answer to count or continue the game, the teacher would gave a questionand gave a point if the students could answer it correctly.

\section{Jumping Game}

Jumping game was a unique game. This game was played with body movement. The role of this game: the students need to jump a step based on the teacher commands. For playing this game, first, the teacher delivering the material about let's start our wall magazine! (modal: should). Then, the teacher asked the students to stand beside their tables or chairs. Next, the teacher would command the students for jumping to the left, right, front or back. To the students who could jump well, the teacher would give a question and gave a point if the students could answer the questions correctly.

\section{Line Game}

Line game was an active game. This game also was played with body movement. The role of this game: the students need to make a line based on the teacher commands. For playing this game, first, the teacher delivering the material about let's start our wall magazine! (modal: have to). Then, the teacher devided the students into four groups and asked them to stand beside their chairs or tables. Next, the teacher would ask the students to make a line from the taller students to the shorter students. After that, automatically the students would make a good line quickly while the teacher was counting one until ten. To the students who could not make a line well, the teacher would gave the questions and asked them to make a sentence.The teacher would give points to the right students and who could make the line well. 
The students' response towards the implemented games by the teacher

A questionnaire was used to garner the data. It comprised ten closed statements and was designed to probe students' opinion on using Bingo Game, Stars Game, Dorr Game, Jumping Game, and

Table 2. Result of the students' response towards the stars game.

\begin{tabular}{|c|c|c|c|c|c|c|}
\hline No. & Statements & SA & A & $\mathbf{N}$ & D & SD \\
\hline 1. & These game encouraged me to talk spontaneously. & $25 \%$ & $75 \%$ & - & - & - \\
\hline 2. & $\begin{array}{l}\text { I feel like continuing to speak spontaneously with } \\
\text { this game. }\end{array}$ & $20 \%$ & $80 \%$ & - & - & - \\
\hline 3. & This game helps hones my speaking spontaneity & $20 \%$ & $80 \%$ & - & - & - \\
\hline 4. & $\begin{array}{l}\text { The teacher creates a motivating speaking class } \\
\text { with this game. }\end{array}$ & $20 \%$ & $70 \%$ & $10 \%$ & - & - \\
\hline 5. & $\begin{array}{l}\text { The speaking class encoureged me to participate } \\
\text { spontaneously in conversation exercises. }\end{array}$ & $40 \%$ & $45 \%$ & $15 \%$ & - & - \\
\hline 6. & I like speaking class because I use game. & $25 \%$ & $45 \%$ & $30 \%$ & - & - \\
\hline 7. & I made a little mistake in speaking through game. & $5 \%$ & $15 \%$ & $65 \%$ & $15 \%$ & - \\
\hline 8. & I became more spontaneous talking through game. & $15 \%$ & $70 \%$ & $15 \%$ & - & - \\
\hline 9. & $\begin{array}{l}\text { This game makes a better development for me in } \\
\text { speaking. }\end{array}$ & $10 \%$ & $85 \%$ & $5 \%$ & - & - \\
\hline 10. & This game is very useful for me. & $25 \%$ & $45 \%$ & $30 \%$ & - & - \\
\hline
\end{tabular}

Adapted from Ramdani \& Rahmat (2018).

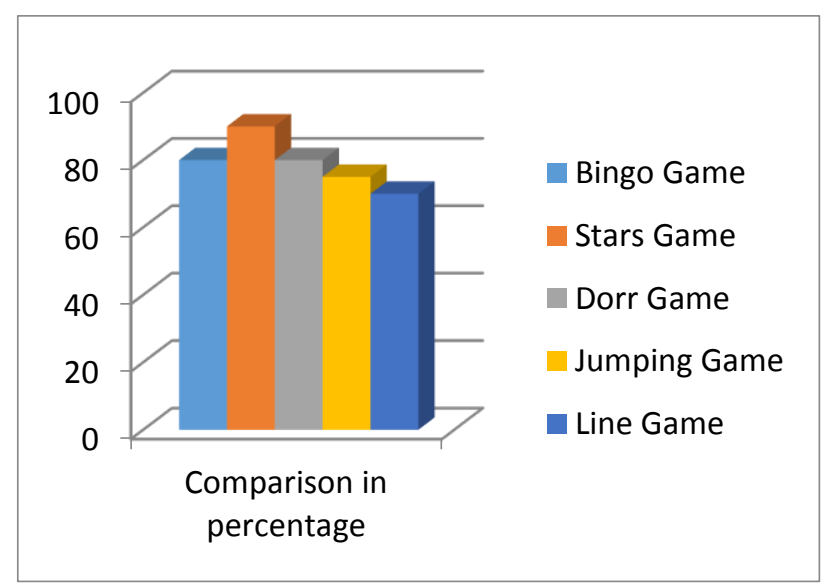

Figure 1. Students' speaking spontaneity score used games. 


\section{Journal of Applied Linguistics \\ 1(1), November 2019}

Based on the comparation data from students' response towards the implemented games, the researcher concluded that most of the students in IX graders at SMP Negeri 15 Tasikmalaya were enjoy and comfortable to used stars game in promoting their speaking spontaneity. The students' chose stars game as their favourite game because of the use of realia such as stars in learning process. It proved with $90 \%$ as the highest percentage and 9,1 as the highest mean score among the others. This statement supports Astutie (2018, p. 45) in her research that using game make the students active in speaking and learning seriously in relax condition, especially in speaking spontaneity. Moreover, Rahmawati (2017, p. 1) also cited in her research, that using games have improved students' speaking ability significantly. Then, the students have good response and positive attitude in speaking spontaneity.

Here, the researcher concluded that using game in speaking class is very useful to promote students' speaking ability, especially in speaking spontaneity. From the data obtained, participants have willingness to be spontaneous speaker. Allsop and Jessel (2015, p. 1) mentioned that teachers need to decide and choose which game can be appropriate for the students to be able to speak spontaneously. Furthermore, both using game for teaching, or teaching through game design can explore the students' potential in speaking spontaneity.

In addition, applying different games genre is very useful and has good benefit to the students to promote their speaking spontaneity skills. From the game that teacher gave to the students, they could learn and practice to speak spontaneously with enjoy condition. Then, students had experience about how to speak spontaneously. However, the researcher agree with Yien $(2011$, p. 1) emphasized that the aim of using game was to explore the influence of applying a game-based learning in speaking spontaneity. Hence, it is important for the teachers in Indonesia to use games for promoting the students' speaking spontaneity skills.

Based on the findings made by the researcher during the learning process from observation and questionnaire that have been distributed to the students in the classroom, the researcher found that: There were few of students still confused what they should say in the speaking class, and still lack of speaking practice, especially in speaking spontaneity. During the meeting conducted, few of the students did not pay their attention, and sometimes they laughed to their friends if there was a mistake although they also did not know the correction. 


\section{Journal of Applied Linguistics \\ 1(1), November 2019}

From the five implemented games, the researcher also got the advantages and disadvantages for each game based on the

Table 3. Advantages and disadvantages of the games students' responses which are shown in Table 3.

\begin{tabular}{lll}
\hline Games & Advantages & Disadvantages \\
\hline Bingo & $\begin{array}{l}\text { Simple and motivating } \\
\text { Stars }\end{array}$ & $\begin{array}{l}\text { Students felt shy to raise their hands and some disliked the } \\
\text { game. } \\
\text { Sots of time to prepare for the "stars" as the teacher made them } \\
\text { manually from paper, less accuracy in speaking practice. }\end{array}$ \\
Jumping & $\begin{array}{l}\text { Students paying attention to } \\
\text { the class, spontaneous } \\
\text { participation } \\
\text { Active and spontaneous } \\
\text { participation } \\
\text { Active and spontaneous } \\
\text { participation }\end{array}$ & $\begin{array}{l}\text { Many students felt the game was useless, needed more } \\
\text { concentration and move quickly. }\end{array}$ \\
& $\begin{array}{l}\text { concentration and moved quickly. } \\
\text { Students needed more concentration, to move quickly, and } \\
\text { many felt they could not speak spontaneously. }\end{array}$ \\
\hline
\end{tabular}

\section{CONCLUSION}

From the research findings, it can be concluded that the teacher used five games, such as bingo game, stars, dorr, jumping, and line to promote students' speaking spontaneity in the classroom. The students' response towards the implemented game chose the stars game as the most interested game among the others. However, most of the students stated that using stars game in speaking class to promote speaking spontaneity skill is very useful for them. As the implication, this research depicted that the used of games in the classroom were still effective. Moreover, the schools in Indonesia were not same in availability of modern equipments. Hence, this research gave pedagogical implication for the teachers to promote the students' speaking spontaneity skill through games.
Therefore, the use of games to promote students' speaking spontaneity based on the researcher's observation, having some advantages and disadvantages. The advantages of using game in learning speaking spontaneity such as: practicing students to be a spontaneous speaker, making students to be active in speaking, having an enjoy learning to the students, and giving good motivation for speaking spontaneously. In the other side, there were many disadvantages of using game in learning speaking spontaneity, for example: a few students may feel unconfident (shy and nervous), a few students may need a long time more to think before speaking.

\section{REFERENCES}

Allsop, Y., \& Jessel, J. (2015). Teachers' experience and reflection on gamebased learning in the primary classroom: Views from England and 
Italy. International Journal of GameBased Learning, 5(1), 1-17.

Arikunto, S. (2005). Prosedur penelitian suatu pendekatan praktek. Jakarta: PT Rineka Cipta.

Astutie, Y. R. E. (2018). Peningkatan kemampuan berbicara bahasa inggris siswa kelas VII SMP negeri 1 kota Blitar melalui games (kalender). Jurnal Pendidikan: Riset \& Konseptual, 2(1), 45-56.

Bandura, A. (1986). Social foundations of thought and action: A social cognitive theory. Englewood Cliffs, NJ: Prentice-Hall.

Boonkit, K. (2010). Enhancing the development of speaking skills for non-native speakers of English. Procedia Social and Behavioral Sciences, 2, 1305-1309.

Bozkirli, K. C. \& Er, O. (2018). Investigating teacher views on improving the speaking skills of syirian students. European Journal of Education Studies, 4(6), 66-67.

Creswell, J. W. (2014). Research design: qualitative, quantitative, and mixed methods approach. Thounsands Oaks, CA: Sage.

Depdikbud. (1994). Kurikulum pendidikan dasar, garis-garis besar program mata pelajaran bahasa inggris. Jakarta: Depdikbud.
Delefosse, S., Gavin, M., Bruchez, A., Roux, C. P., \& Stephen, S. L. (2016). Quality of qualitative research in the health sciences: Analysis of the commoncriteria present in 58 assessment guidelines by expert users. Social Science \& Medicine, pp. 142151.

Felicia, P. (2009). Digital games in schools. A handbook for teachers. Brussels, Belgium: European Schoolnet. In Allsop, Y., \& Jessel, J. (2015). Teachers' experience and reflection on game-based learning in the primary classroom: Views from England and Italy. International Journal of Game-Based Learning, 5(1), 1-17.

Goh, C. C. M. (2014, October). Foregrounding metacognition in second language oracy: A call for visible learning of listening and speaking. In Ramdani, J.M., \& Rahmat. (2018). Promoting speaking spontaneity in large classes: An action research study in an Indonesian EFL university setting. Indonesian Journal of Applied Linguistics, 8(2), 388-401.

Harinie, L. T., Sudiro, A., Rahayu, M., \& Fatchan, A. (2017). Study of Bandura's social cognitive learning theory for the entrepreneurship learning process. Social Science, 6(1), 1-6. 
Harmer, J. (2007). The practice of English language teaching (4th Ed.). Essex: Pearson Longman.

Humphries, S. C., Burns, A., \& Tanaka, A. (2015). "My head became blank and I couldn't speak": Classroom factors that influence English speaking. The Asian Journal of Applied Linguistics, 2(3), 164-175.

Hussain, S. (2017). Teaching speaking skills in communication classroom. International Journal of Media, Journalism and Mass Communications, 3(3), 14-21.

Kosar, G., \& Bedir, H. (2014). Strategiesbased instruction: A means of improving adult EFL learners' speaking skills. International Journal of Language Academy. In Rahmawati. (2017). Improving English speaking ability using the team-gamestournament technique. English Education Journal, 8(1), 1-13.

Kroeker, R. H. (2009). The reality of English conversation classes: A study in a South Korean university. Unpublished Doctoral thesis. University of Birmingham: United Kingdom.

Layman. (1972). Technique in testing. New York: Oxford University Press.

Rahmaniar. (2010). Improving the students' speaking proficiency through presentation, practice and production approach (a classroom action research at the third grade in class a of MTs islamic boarding school muhammadiyah Pinrang. Thesis of UNISMUH.

Rahmawati. (2017). Improving English speaking ability using the teamgames-tournament technique. English Education Journal, 8(1), 1-13.

Ramdani, J. M., \& Rahmat. (2018). Promoting speaking spontaneity in large classes: An action research study in an Indonesian EFL university setting. Indonesian Journal of Applied Linguistics, 8(2), 388-401.

Sevy-Biloon, J. (2017). Different reasons to play games in an English language class. Journal of Education and Training Studies, 5(1), 84-93.

Urrutia L. W., \& Vega C. E. (2010). Encouraging teenagers to improve speaking skills through games in a Colombian public school. Profile, 12(1), 11-31. Bogotá, Colombia.

Widodo, H. P. (2015a). Designing and implementing task-based vocational English materials: Text, language, task, and context in Indonesia. In Ramdani, J. M., \& Rahmat. (2018). Promoting speaking spontaneity in large classes: An action research study in an Indonesian EFL university setting. Indonesian Journal of Applied Linguistics, 8(2), 388-401. 
Widodo, H. P. (2015b). The development of vocational English materials from a social semiotic perspective: Participatory action research. In Ramdani, J. M., \& Rahmat., (2018). Promoting speaking spontaneity in large classes: An action research study in an Indonesian EFL university setting. Indonesian Journal of Applied Linguistics, 8(2), 388-401.

Willis, D. (2015). Conversational English: Teaching spontaneity. In Ramdani, J. M., \& Rahmat. (2018). Promoting speaking spontaneity in large classes: An action research study in an Indonesian EFL university setting. Indonesian Journal of Applied Linguistics, 8(2), 388-401.

Yalcin, O., \& Incecay, V. (2014). Foreign language speaking anxiety: The case of spontaneous speaking activities. Procedia - Social and Behavioral Sciences, 2620-2624.

Yegani, H. \& Jodaei, H. (2017). The effect of task-based and topic-based speaking activities on speaking ability of Iranian EFL learners. International Journal of English Language \& Translation Studies, 5(4). 85- 93.

Yien, J. M., Hung, C. M., Hwang, G. J., \& Lin, Y. C. (2011). A game-based learning approach to improving students' learning achievements in a nutrition course. The Turkish Online
Journal of Educational Technology, $10(2), 1-10$. 